\begin{tabular}{lll}
\hline Volume: 2 & No.1 Januari - Juni 2017 & ISSN: 2502-7067 \\
\hline
\end{tabular}

\title{
PERENCANAAN PROGRAM PENINGKATAN KINERJA GURU SEKOLAH DASAR INKLUSIF DI KABUPATEN LOMBOK BARAT
}

\section{Imanto Rahadi}

\begin{abstract}
Abstrak: Sekolah dasar inklusif telah ditunjuk, berarti implementasinya dijadikan dasar untuk memberikan pendidikan yang non deskrimatif pada siswa non ABK dan ABK (anak berkebutuhan khusus). Ada banyak masalah yang ditemukan, terutama kinerja guru yang belum dapat dinyatakan optimal. Penelitian ini fokus untuk melakukan eksplorasi dan analisis atas kondisi kinerja guru SD inklusif, perencanaan program peningkatan kinerjanya serta faktor yang menjadi pendukung dan penghambatnya di Kabupaten Lombok Barat. Desain dengan pendekatan kualitatif, sehingga sangat mengandalkan kedalaman dan keluasan informasi dari responden. Rancangan kajian dilihat dari wilsayah penelitian merupakan lingkup pendidikan di Kabupaten Lombok Barat, sehingga temuan dan analisisnya dapat dijadikan rujukan untuk mengambil kebijakan oleh dinas pendidikan. Temuan dalam penelitian ini tergolong diluar ekspektasi bahwa kinerja guru inklusif tergolong kurang dan sedang, di mana dua kriteria ini pada dasarnya adalah rendah. Kriteria cukup hanya ditemukan pada sekolah yang pernah menjadi lokasi kerja handicap internasional. Perencanaan peningkatan kinerja guru SDN inklusi pada satuan kerja wilayah Kabupaten Lombok Barat melalui Dinas Dikpora Kabupaten Lombok Barat dapat dinyatakan nihil. Hambatan utama dari perencanaan peningkatan kinerja guru dalam satuan wilayah kerja Kabupaten Lombok Barat dan satuan pendidikan adalah belum adanya Perda yang mengatur mengenai pendidikan inklusi. Hal ini berdampak luas pada penggunaan sumber daya yang bersumber dari APBN. Satu-satunya potensi yang ada adalah etos kerja guru dalam pelaksanaan pendidikan inklusi yang tergolong tinggi.
\end{abstract}

\section{PENDAHULUAN}

Manusia dalam pembangunan merupakan subyek dan obyek yang vital, mengungguli faktor lainnya. Sumber daya manusia (SDM) yang ada, tanpa kecuali harus muncul sebagai pemberi kontribusi atas pembangunan. Hal ini dapat terwujud, jika seluruh lapisan dan spesifikasi SDM mendapatkan pendidikan yang layak. Konsep tersebut dapat saja menjadi latar belakang pendidikan inklusif, di luar aspek haknya sebagai manusia. Pendidikan di Indonesia juga mengenal pendidikan khusus atau inklusif, sesuai dengan pasal 32 UU No. 20 Tahun 2003, bahwa Pendidikan khusus merupakan pendidikan bagi peserta didik yang memiliki tingkat kesulitan dalam mengikuti proses pembelajaran karena kelainan fisik, emosional, mental, sosial, dan/atau memiliki potensi kecerdasan dan bakat istimewa. Dalam prakteknya tidak dibedakan dengan siswa non $\mathrm{ABK}$, tetapi makna non deskriminasi juga terkait dengan tempat pendidikan yang sama. Atau dibaurkan antara siswa reguler dan ABK.

Dalam praktek pendidikan inklusif dipastikan pembelajaran yang diampu oleh guru semakin berat, karena karakteristik siswa yang semakin beragam. Fakta yang ada di Kabupaten Lombok Barat telah diterbitkan surat keputusan (SK) Kepala Dinas Dikpora atas 41 SDN untuk menyelenggarakan 
pendidikan SD inklusif, sebagai implementasi dari perintah yang diberikan pemerintah pusat melalui pemerintah provinsi. Observasi awal dilakukan di SDN I Labuhan Tereng kecamatan Lembar dan SDN 3 Beleke kecamatan Gerung, ditemukan siswa ABK dengan kuantitas masing-masing sebanyak 27 orang dan 35 orang, dengan proporsi yang berbeda pada setiap kelas. Temuan awal di dua SDN tersebut, siswa ABK-nya belum mengalami ketuntasan pembelajaran, tentu dengan grade yang telah diturunkan dari grade standar siswa reguler (non $\mathrm{ABK}$ ).

Tarmansyah (2009) dalam risetnya menemukan bahwa belum dimiliki acuan formal dalam pelaksanaan pendidikan inklusif. Ni'matuzahroh (2015) menemukan bahwa kriteria yang minim untuk sarana dan prasarana, belum adanya kurikulum untuk pendidikan inklusif, pemahaman guru yang masih rendah atas pendidikan inklusif, termasuk keterampilan dalam pengelolaan pembelajaran. Optimalisasi output pembelajaran pendidikan inklusif akan dapat terwujud, jika permasalahan tersebut dapat diatasi, utamanya kinerja guru. Penelitian ini fokus pada kajian kinerja guru, rencana yang ditetapkan oleh Dinas Dikpora Kabupaten Lombok Barat dan kajian lebih lanjut untuk perbaikan dengan cara mengevaluasi faktor pendukung dan penghambatnya.

\section{RUMUSAN MASALAH}

Pokok permasalahan yang diajukan adalah:

1. Bagaimanakah kondisi kinerja guru SD inklusif di Kabupaten Lombok Barat?

2. Bagaimanakah perencanaan program peningkatan kinerja guru SD inklusif di Kabupaten Lombok Barat?

3. Faktor-faktor apakah yang menjadi penghambat dan pendukung perencanaan program peningkatan kinerja guru SD inklusif di Kabupaten Lombok Barat?

\section{TINJAUAN TEORITIS DAN KERANGKA PEMIKIRAN}

Tarmansyah (2009) dalam penelitiannya menemukan bahwa pendidikan inklusif belum berjalan dengan baik. Upaya perbaikan yang diharapkan berupa a) adaptasi kurikulum, b) peningkatan kompetensi guru, terkait dengan pengetahuan mengenai visi dan misi pendidikan inklusif, terampil mengatasi masalah anak, pengetahuan interaksi sosial siswa, komunikasi kemitraan dan kolaborasi anak serta c) peran orang tua. Prastiyono (2013) dalam penelitiannya atas aspek implementasi kebijakan pendidikan inklusif juga belum berjalan dengan baik. Kondisi tersebut disebabkan personel yang melakukan sosialisasi tidak mempunyai kompetensi yang optimal.

Tardi (2011) mengidentifikasi hambatan dalam pelaksanaan pendidikan inklusif berupa (1) pemberian tanggung jawab yang tidak merata dalam penanganan pendidikan inklusif; (2) terbatasnya standar prosedur dalam mengidentifikasi anak penyandang disabilitas (APD); (3) minimnya data APD di luar sekolah; (4) kurangnya kesadaran mengenai isu disabilitas; (5) kurangnya kesadaran mengenai isu pendidikan inklusif; (6) kurangnya kesadaran orang tua/pengasuh mengenai hak memperoleh pendidikan untuk APD; (7) akses fisik yang masih kurang, baik di dalam ataupun luar sekolah; (8) kurikulum belum diadaptasi untuk pendidikan APD; (9) kurangnya partisipasi orang tua/pengasuh APD; (10) kurangnya kapasitas guru dan pendukung lainnya serta (11) hambatan sikap dan perilaku.

Penelitian terdahulu yang melakukan kajian beberapa aspek mengenai pendidikan inklusif ditemukan 
pelaksanaan yang belum baik, banyak ragam permasalahan dan lainnya. Pendidikan inklusif di Indonesia sebagai upaya untuk merealisasikan ratifikasi perundangan secara global. Pendidikan inklusif telah menjadi isu global, di mana Indonesia juga menyadari makna pentingnya bagi pendidikan anak bangsa yang tidak diskriminatif. Prinsip dalam pendidikan inklusid adalah 1) selama memungkinkan semua anak seyogyanya belajar bersama-sama, tanpa memandang kesulitan atau perbedaan dan 2) APD dalam pembelajaran memperoleh dukungan untuk kelancaran pembelajaran (Sunaryo, 2009). Sekolah inklusif dicirikan dengan fleksibilitas, pembelajaran yang berpusat pada siswa, nilai yang dimiliki seluruh murid, tanggap atas perbedaan, menerima guru yang disabilitas (UNESCO dalam Alimin, 2005).

Kinerja guru yang masih belum optimal menjadi salah satu hambatan berjalannya pendidikan inklusif dengan baik. Untuk itu, perlu dikenali makna kinerja secara umum yang diaplikasikan untuk profesi guru. Sihotang (2007:186) mengidentifikasikan aspek-aspek yang terdapat dalam kinerja berupa (a) kecakapan dan kemampuan; (b) panampilan karyawan (profesionalisme); (c) kebugaran jasmani dan rohani selama bekerja; (d) pembuatan laporan dan pertanggunjawaban pelaksanaan pekerjaan; dan (e) loyalitas pada organisasi. Adapun secara spesifik Kementerian Pendidikan dan Kebudayaan (2012) menetapkan komponen pengukur kinerja mata pelajaran berupa a) perencanaan pembelajaran meliputi guru memformulasikan tujuan pembelajaran dalam RPP, guru menyusun bahan ajar secara runut, logis dan mutakhir, merencanakan kegiatan pembelajaran yang efektif, memilih sumber belajar dan media pembelajaran sesuai dengan materi dan strategi pembelajaran; b) pelaksanaan kegiatan pembelajaran yang aktif dan efektif, meliputi (1) kegiatan pendahuluan (memulai pembelajaran dengan efektif), (2) kegiatan inti (guru menguasai materi pelajaran, guru menerapkan pendekatan pembelajaran yang efektif, guru memanfaatkan media dalam pembelajaran, guru memicu dan memelihara keterlibatan siswa dalam pembelajaran serta guru menggunakan bahasa yang benar dan tepat dalam pembelajaran; serta c) egiatan penutup; meliputi guru mengakhiri pembelajaran dengan efektif, penilaian pembelajaran, guru merancang alat evaluasi untuk mengukur kemajuan dan keberhasilan peserta didik, guru menerapkan strategi dan metode penilaian untuk memantau kemajuan pembelajaran serta guru melakukan umpan balik.

Dalam rangka meningkatkan kinerja guru, maka perlu direncanakan peningkatan kinerjanya. Aspek yang perlu diperhatikan dalam perencanaan peningkatan kinerja pegawai secara umum, termasuk guru adalah (a) menetapkan tujuan atau serangkaian tujuan; perencanaan dimulai dengan keinginan atau kebutuhan organisasi, (b) merumuskan keadaan saat ini. Kajian kondisi internal organisasi; (c) mengidentifikasi segala kemudahan dan hambatan serta (d) mengembangkan rencana atau serangkaian kegiatan untuk mencapai tujuan (Handoko, 2001:46). Adapun Matin (2013) merumuskan prosesnya sebagai berikut: (a) pengumpulan dan pengolahan data; (b) perumusan kebijaksanaan; (c) perkiraan kebutuhan; (d) penetapan kebutuhan biaya; (e) penetapan sasaran; (f) perumusan rencana; (g) perincian rencana; (h) implementasi rencana serta (i) revisi dan perencanaan ulang.

Dalam penelitian in, proses penilaian kinerja guru, perencanaan peningkatan kinerja guru dan temuan atas 
faktor pendukung dan penghambatnya, konseptual berikut. mengikuti proses dalam kerangka

Gambar 1. Kerangka Konseptual Penelitian

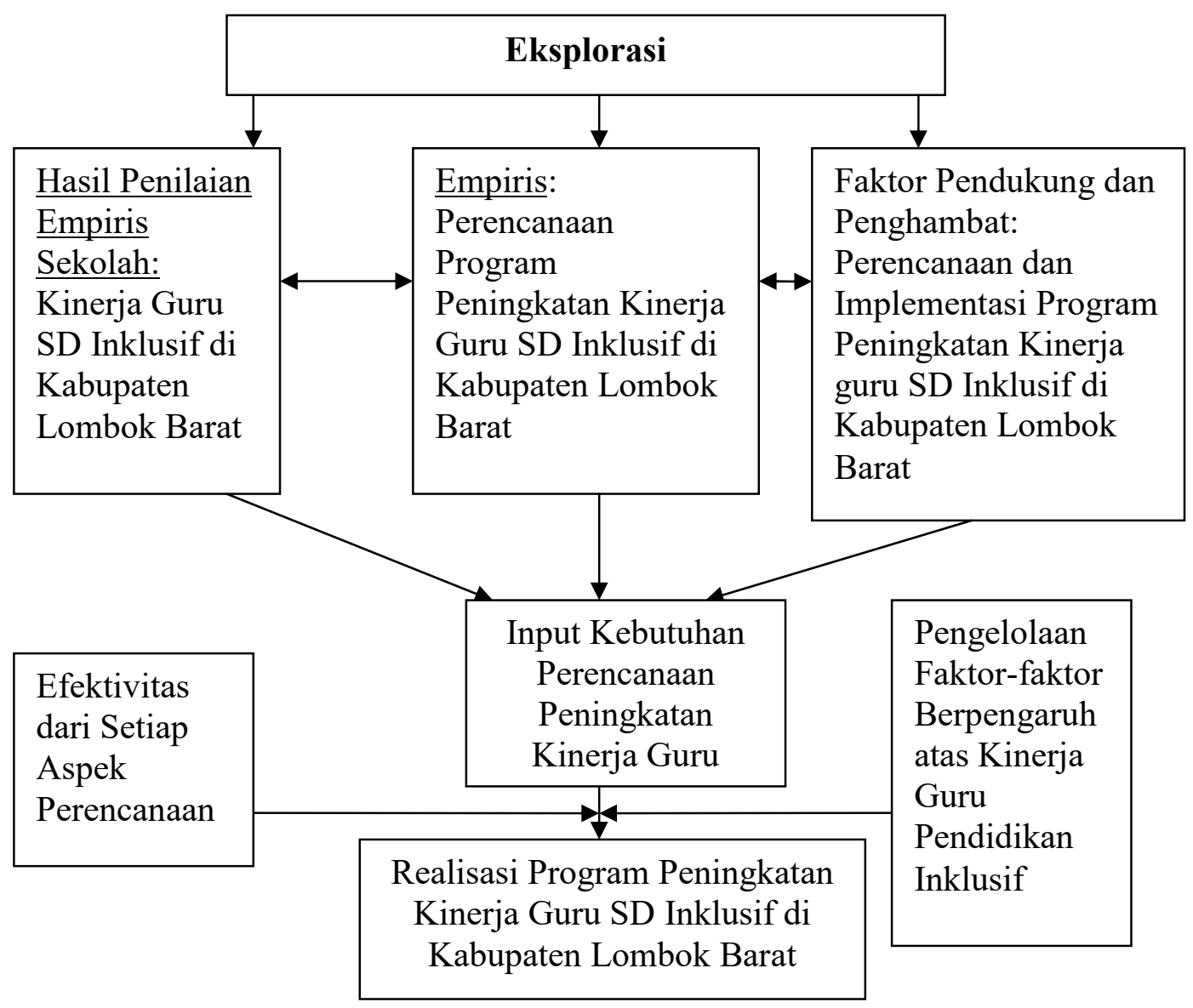

\section{METODE PENELITIAN}

Jenis penelitian yang digunakan penelitian kualitatif. Sarwono (2006:193), memaknai penelitian kualitatif sebagai "proses yang mencoba untuk mendapatkan pemahaman yang lebih baik mengenai kompleksitas yang ada dalam interaksi manusia”. Pendekatan kualitatif digunakan untuk melakukan eksplorasi mengenai kinerja aktual guru SD yang memberlakukan pendidikan inklusif (selanjutnya disebut SD inklusif) di Kabupaten Lombok Barat, pelaksanaan perencanaan program peningkatan kinerja yang telah dipraktekkan dan temuan atas faktor pendukung serta penghambat dalam implementasinya. Seluruhnya bersifat temuan, di mana kompleksitas temuannya tergantung pada kemampuan peneliti melakukan wawancara mendalam atau menggunakan teknik lainnya.

Responden penelitian ini dalam prakteknya terkait dengan seluruh personel publik di Kabupaten Lombok Barat, terkait dengan temuan mengenai aspek-aspek pendidikan, bahkan yang melingkupinya. Responden ini berupa para kepala sekolah SDN inklusif, pengawas sekolah, guru dan personel pengambil kebijakan di Dinas Dikpora 
Kabupaten Lombok Barat. Proses kerja yang digunakan mengacu pada konsep yang dibangun oleh Miles dan Huberman (Sugiyono, 2011). Proses yang menjadi cirinya adalah pengumpulan data secara berulang pada setiap tahap, mulai dari kerja pengumpulan data, reduksi, penyajian dan pengambilan simpulan. Kekuatan dalam penelitian ini dengan mengandalkan proses dalam pengumpulan data pada sumber informasi.

\section{HASIL DAN PEMBAHASAN}

\subsection{Hasil Penelitian}

Pendidikan dasar di Kabupaten
Lombok Barat masih dilingkupi permasalahan yang sifatnya mendasar, yaitu kualifikasi pendidik. Persentase guru yang berpendidikan sarjana sangat rendah, hanya pada kisaran 1,49\%. Penelusuran atas data tersebut dilakukan, di mana ada aparatur negara yang menerimanya dan lebih fokus dalam mencarikan solusi serta ada yang menyatakan bahwa persentase tersebut telah mengalami pergeseran. Fakta menunjukkan bahwa rata-rata pencapaian hasil uji kompetensi guru di Indonesia tahun 2015 sebesar 43,68, Provinsi NTB sebesar 42,79 dan Kabupaten Lombok Barat 41,62. Adapun khusus untuk SDLB (Sekolah Dasar Luar Biasa), rata-rata hasil UKG tingkat nasional 46,47 , ratarata Provinsi NTB 40,86 dan tingkat Kabupaten Lombok Barat sebesar 39,05 (LPMP Provinsi NTB, 2016).

Wawancara dengan pejabat di Dinas Dikpora Kabupaten Lombok Barat atas temuan di atas, sebagai berikut:

Pihak LPMP telah melakukan perhitungan hasil UKG, secara regional dan nasional... masing-masing daerah mempunyai kajian tersendiri atas data tersebut. Kita di
Kabupaten Lombok Barat, jelas mengakui bahwa kualitas guru SD lebih rendah dari kondisi di provinsi dan nasional.... jelas kualitas pembelajaran dan akhirnya kualitas keluaran mempunyai daya saing yang rendah...pelatihan menjadi salah satu orientasi untuk mengatasi masalah ini, baik secara formal ataupun melalui tugas-tugas yang dijalankan oleh kepala sekolah dan pengawas dalam memberikan supervisi akademik.... ini yang perlu kita perkuat kembali... (wawancara tanggal 2 Maret 2016).

Satu sisi dilihat dari fakta dalam pelaksanaan pendidikan SD inklusif, bahwa pelaksanaannya telah berjalan, bahkan terbitnya SK penunjukkan SDN inklusif leboh banyak didahului dengan peran aktif SDN untuk mengajukan diri sebagai pelaksana. Alasan utamanya adalah pembelajaran telah berjalan dan diharapkan ragam pembinaan dan dukungan untuk mensukseskan pembelajaran bagi anak reguler dan ABK. Hal ini mengacu pada hasil wawancara dengan beberapa kepala sekolah dan berikut salah satu hasil wawancaranya:

... Pada dasarnya telah ada anak ABK di setiap kelas kami dengan intensitas perhatian yang beragam. Awal sebelum ditunjuk sebagai sekolah inklusi, kami telah menerima mereka dengan alasan "hak dan kemanusian"... latar belakang para siswa ABK tergolong miskin, 
sulit bagi mereka

memberikan pendidikan

yang letaknya relatif jauh

dari tempat tinggal

(wawancara tanggal 16

Maret 2016).

Organisais pendidikan dan guru mempunyai kesadaran mengenai pelaksanaan pendidikan inklusif untuk anak ABK, karena seluruhnya merupakan anak bangsa yang mempunyai hak yang sama mendapatkan pendidikan serta berpotensi untuk berkontribusi dalam pembangunan., bukan sebagai beban dari pembangunan itu sendiri. Terkait dengan kinerja guru dalam pembelajaran inklusi, ditemukan secara umum dari penilaian pengawas sekolah masih tergolong kurang dan sedang. Dua kriteria ini pada sistem penilaian kinerja guru pada dasarnya tergolong rendah. Kinerja guru SDN inklusi yang tergolong cukup hanya terjadi pada SDN 1 Labuan Tereng dan SDn 1 Batu Layar. Dua SDN inklusif ini pernah mendapatkan pelatihan dari pihak handicap internasional, LSM internasional yang fokus pada pendidikan inklusif.

Berhubungan dengan perencanaan peningkatan kinerja guru SDN inklusi di Kabupaten Lombok Barat dari pihak Dinas Dikpora Kabupaten Lombok Barat, ditemukan nihil. Kajian dari hasil wawancara, telusur kebijakan, telusur rencana kerja dan termasuk permintaan alokasi anggaran dari APBD melalui KUA (kebijakan umum anggaran) tidka ditemukan rencana peningkatan kinerja guru SDN inklusi. Pendidikan inklusi secara umum juga tergolong nihil.

Fakta ini mengharuskan peneliti melakukan penelusuran dan kajian mendalam pada setiap SDN inklusi di Kabupaten Lombok Barat. Seluruh SDN inklusi pada rencana kerjanya yang tersusun dalam RKAS dan RKT memasukkan rencana kerja untuk mendapatkan pelatihan, bantuan sarana dan prasarana kerja. Para pengelola manajemen sekolah juga menghadapi rintangan dalam pelaksanaan pekerjaan, berupa belum adanya peraturan yang memperbolehkan dana BOS untuk alokasi kerja pendidikan inklusi.

Proses perumusan perencanaan peningkatan kerja guru SDN inklusi melalui focus group discusion setelah peneliti terlebih dahulu memberikan uraian temuan kondisi internal dan eksternal keberadaan pendidikan inklusif di Kabupaten Lombok Barat. Ringkasan hasil yang diperoleh adalah a) mendesak pemerintah melalui Dinas Dikpora Kabupaten Lombok Barat agar segera mengajukan Perda yang mengatur pelaksanaan pendidikan SDN inklusi di Kabupaten Lombok Barat. Desakan tersebut dapat juga dilakukan secara langsung pada DPRD Kabupaten Lombok Barat agar menggunakan hak inisiatifnya dalam menyusun Perda tersebut; b) desakan tersebut diupayakan dengan menyertakan kepala sekolah, guru dan pengawas di 41 SDN inklusi di Kabupaten Lombok Barat. Rencana kerja selanjutnya hasil FGD adalah 1) menyusun kurikulum untuk pendidikan SD inklusi, sehingga ada kesamaan konsepnya di seluruh Kabupaten Lombok Barat dan acuan yang sama dalam melaksanakan pembelajaran oleh para guru; 2) adanya buku teks yang dapat dipedomani dalam pembelajaran setiap mata pelajaran dan semua kelas di SDN inklusi, baik untuk kepentingan optimalisasi pembelajaran siswa ABK dan non $\mathrm{ABK}$; 3) memberikan pelatihan pada para guru yang mengelola kelas inklusi. Pelatihan tersebut fokus pada pemenuhan kebutuhan untuk meningkatkan kualitas pembelajaran, bagaimana mengidentifikasi kebutuhan para siswa dan menerapkan metode pembelajaran yang efektif; 4) memberikan pelatihan untuk mendukung 
kemampuan berkomunikasi dengan para siswa ABK. Komunikasi yang baik dengan para murid menjadi aspek utama dalam pembelajaran dan guru harus mampu melakukannya; 5) pelatihan tersebut bersifat berkelanjutan, dengan melakukan evaluasi hasil; 6) diupayakan pelatihan juga bersifat langsung, dengan cara mendatangkan guru-guru yang telah berpengalaman dalam mengelola kelas inklusi; 7) meningkatkan kemampuan para guru berkomunikasi dengan para orang tua dan masyarakat agar keberadaannya memberikan dukungan bagi para siswa ABK di pendidikan inklusi. Hal ini diharapkan langsung sebagai edukasi untuk masyarakat, utamanya pada orang tua; 8) tersedianya fasilitas yang memadai sesuai dengan ragam hambatan pada siswa, agar siswa ABK bukan menjadi pelengkap di kelas ataupun di lingkungan sekolah serta 9) siswa ABK mendapatkan fasilitas langsung dari dana BOS atau sejenisnya agar dapat mengikuti pembelajaran dengan lebih baik.

\subsection{Refleksi Penelitian}

Pendidikan inklusi telah menjadi pilihan pemerintah pusat yang diperintahkan untuk dilaksanakan oleh pemerintah daerah, termasuk di wilayah Kabupaten Lombok Barat. Dalam implementasinya terdapat 41 unit SDN, yang dalam prosesnya ditunjuk dan mengajukan diri sebagai pelaksana pendidikan inklusi tingkat dasar. Fakta kinerja guru, perencanaan program peningkatan kinerja guru di tingkat wilayah, gugus dan satuan pendidikan telah mendapatkan uraian. Satu hal penting yang perlu mendapatkan penjelasan dalam refleksi penelitian ini adalah bagaimana pembelajaran di SDN inklusi Kabupaten Lombok Barat.

Dalam sistem pendidikan di Indonesia, awalnya secara tegas memisahkan antara proses pembelajaran siswa $\mathrm{ABK}$ dengan siswa non $\mathrm{ABK}$, tetapi dalam perkembangan konsepnya, ternyata membutuhkan proses pembelajaran yang bersamaan. Beberapa nilai yang terlihat, selama proses observasi pada pembelajaran di kelas inklusi adalah terbiasa bergaul dengan antara siswa $\mathrm{ABK}$ dan non $\mathrm{ABK}$, tidak ada perbedaan perlakuan satu sama lainnya. Kondisi pergaulan ini sangat dibutuhkan dalam kehidupan aktual di masyarakat, satu pihak tidak merasa menjadi beban atau sebaliknya pada pihak lain. Pembelajaran di kelas tidak terjadi pengacuhan pada tingkat materi yang diajarkan pada siswa ABK. Kondisi ini diharapkan berimplikasi pada kehidupan aktual dalam masyarakat, bahwa individu yang mengalami kelainan hanya perlu mendapatkan penyesuaian atas permasalahan yang dipecahkan dengan kemampuan yang dimiliki.

Pembelajaran di atas pada SDN inklusi dengan siswa ABK yang hanya mempunyai permasalahan kelambanan, temuan pada SDN 1 Batu Layar, khususnya pada kelas dengan siswa tuna netra, terjadi hubungan antar siswa dengan sangat baik. Siswa reguler memberikan bantuan sebatas yang diperlukan, jika yang bersangkutan mampu dibiarkan untuk mandiri. Siswa menyesuaikan permainan dengan rekannya yang mengalami permasalahan tersebut, bukan memaksa dan menjadikannya sebagai pihak yang perlu dikasihi.

Pada siswa yang membutuhkan perhatian khusus, misalnya mengalami hambatan pada perilaku yang relatif tidak terkendali ada upaya dari siswa reguler untuk mengalah guna berjalannya proses pembelajaran dengan baik. Siswa tidak menunjukkan kekesalan atau menjadikan siswa ABK sebagai penghambatnya dalam pelaksanaan proses pembelajaran.

Temuan di atas selama proses observasi mendalam atas proses pembelajaran, maka pendidikan inklusi 
sangat penting untuk dilaksanakan secara total. Keberadaan individu ABK dalam masyarakat telah nyata adanya, di mana pembelajaran inklusi sejak dini menjadi cara yang paling tepat untuk memberikan pembelajaran agar dapat saling memberikan posisi yang tepat satu sama lainnya. Ada upaya dari awal untuk memberikan posisi satu sama lain dengan kondisi masing-masing, bukan menjadikan individu ABK sebagai pihak yang memerlukan belas kasih semata (charity). Pendidikan inklusi akan memberikan peningkatan kompetensi dan perilaku yang tepat satu sama lainnya.

Di Kabupaten Lombok Barat pendidikan inklusi secara resmi berdasarkan SK Dinas Dikpora Kabupaten Lombok Barat telah berjalan kurang lebih tiga tahun. Implikasi positif yang diharapkan dari proses pembelajaran tersebut telah terlihat, tidak ditemukan gejolak dalam pelaksanaannya. Satu hal penting yang menjadi permasalahannya adalah kinerja guru yang masih rendah.

Sebelum dilakukan kajian atas kinerja guru tersebut, yang utama untuk perlu dilakukan dalam kelas inklusi adalah guru diupayakan lebih dari satu orang. Kemampuan pergerakan guru, membagi perhatian, membagi waktu dan hal lainnya dalam proses pembelajaran dengan karakteristik siswa yang beragam, dibutuhkan minimal dua orang. Posisi yang diberikan adalah satu guru sebagai asisten guru kelas, karena siswa ABK membutuhkan perhatian dalam wujud kontak dengan guru.

Pilihan pendidikan inklusi merupakan wujud kebijakan publik dalam sektor pendidikan. Pemerintah pusat dan pemerintah daerah harus selalu melakukan koordinasi dan bekerja berdasarkan sistem yang telah ada dalam pengelolaan publik. Pemerintah bekerja berdasarkan perundangan, seyogyanya dengan cepat dilakukan upaya operasionalisasinya melalui penyusunan Perda. Fakta ini tidak terjadi pada pelaksanaan pendidikan inklusi di Kabupaten Lombok Barat, berimplikasi pada tidak berlanjutnya kebijakan tersebut dalam kebijakan lanjutan untuk pengembangan atau pemecahan masalah yang ada.

Dapat dinyatakan bahwa Dinas Dikpora Kabupaten Lombok Barat nihil atau absen dalam memberikan perhatian lanjutan atas SDN inklusi pasca penunjukkan pada tahun 2013. Pihak satuan pendidikan telah melakukan perencanaan dan aksi langsung, tetapi tanpa dukungan kebijakan dan alokasi dana dari APBD, maka berimplikasi sangat minim untuk optimalisasi hasil pembelajaran inklusi yang diawali dengan kinerja guru yang memadai.

Satu hal penting, bahwa perlu desakan publik melalui personel yang ada pada 41 SDN inklusi, ditambah dari pihak lain yang mampu digerakkannya pada DPRD Kabupaten Lombok Barat. Diupayakan penyusunan Perda disegerakan, walaupun belum masuk dalam agenda. Desakan dilakukan melalui komisi IV yang mengurus masalah pendidikan. Terbitnya Perda akan menjadi awal yang sangat baik dalam merumuskan perencanaan peningkatan kinerja, baik melalui kerja satuan wilayah Dinas Dikpora Kabupaten Lombok Barat, selanjutnya lebih dioperasionalkan sesuai dengan kondisi setiap sekolah melalui perencanaan satuan pendidikan.

\section{DAFTAR PUSTAKA}

Alisson, M., dan Kaye., J. 2013. Perencanaan Strategis Bagi Organisasi Nirlaba. Jakarta: Yayasan Pustaka Obor Indonesia.

Bahri, S. 2011. Faktor yang
Mempengaruhi Kinerja Guru SD
di Dataran Tinggimoncong 
Kabupaten Gowa Provinsi Sulawesi Selatan. Jurnal Medtek. Vol. 3. no.2.

Balai Pustaka. 1995. Kamus Besar Bahasa Indonesia. Jakarta: Balai Pustaka.

Departemen Pendidikan dan Kebudayaan Nasional. 2012. Pedoman Pelaksanaan Penilaian Kinerja Guru. Jakarta.

2009. Peraturan Menteri Pendidikan Nasional Republik Indonesia No. 70 Tahun 2009 tentang Pendidikan Inklusif Bagi Peserta Didik Yang Memiliki Kelainan Dan Memiliki Potensi Kecerdasan Dan/Atau Bakat Istimewa. Jakarta.

.2015. Renstra Kementerian Pendidikan dan Kebudayaan Nasional Republik Indonesia Periode 2015-2019. Jakarta.

Dessler, G. 1997. Manajemen Sumber Daya Manusia. Jakarta: PT. Prenhallindo.

Fattah, N. 2013. Sistem Penjaminan Mutu Pendidikan. Bandung: PT. Remaja Rosdakarya.

Gibson L. James, dkk. 1997. Organisasi; Perilaku, Struktur, Proses. Jakarta: Bina Aksara.

Handoko, T.H. 2001. Pengantar Manajemen. Yogyakarta: BPFE UGM.

Hartanto, F.M. 2009. Paradigma Baru Manajemen Indonesia; Menciptakan Nilai dengan Bertumpu pada Kabajikan dan Potensi Insani. Bandung: PT. Integre Quadro.

Mangkunegara, A.P. 2003. Perencanaan dan Pengembangan Sumber daya Manusia. Bandung: Reflika Aditama.

Matin. 2013. Dasar-dasar Perencanaan Pendidikan. Jakarta: PT. RajaGrafindo Persada.
Moleong J.L. 2000. Metodologi Penelitian Kualitatif. Bandung: PT. Remaja Rosda Karya.

Musfah, J. 2013. Peningkatan Kompetensi Guru: Melalui Pelatihan dan Sumber Belajar Teori dan Praktik. Jakarta: Kencana.

Ni'matuzahroh. 2015. Analisis Kesiapan Guru dalam Pengelolaan Kelas Inklusi. Seminar Psikologi dan Kemanusiaan.

Prastiyono. 2013. Implementasi Kebijakan Pendidikan Inklusif (Studi Di Sekolah Galuh Handayani Surabaya). Jurnal Administrasi Publik. Vol. XI No.1.

Rangkuti, F. 2004. Analisis SWOT Teknik Membedah Kasus Bisnis. Jakarta: PT. Gramedia.

Rivai, V. dan Basri, A.F.M. 2005. Performance Appraisal. Jakarta: PT. RajaGrapindo Persada.

Robbins, P.S. 2003. Perilaku Organisasi. Jakarta: PT. Indeks.

Robinson B. R. dan Pearce A. J. 1997. Manajemen Strategik; Formulasi, Implementasi dan Pengendalian Jilid I. Jakarta: Binarupa Aksara.

Rudiyati, S. 2013. Peningkatan Kompetensi Guru Sekolah Inklusif Dalam Penanganan Anak Berkebutuhan Pendidikan Khusus Melalui Pembelajaran Kolaboratif. Jurnal Cakrawala Pendidikan. Vol. XXXII. No. 2.

Ruscoe, G.C. 2000. Kondisi untuk Keberhasilan Perencanaan Pendidikan. Jakarta: Karya Aksara.

Sarwono, J. 2006. metode Penelitian Kuantitatif \& Kualitattif. Yogyakarta: Graha Ilmu.

Sedarmayanti. 2007. Manajemen Sumber Daya Manusia; Reformasi Birokrasi dan Manajemen 
Pegawai Negeri Sipil. Bandung: Reflika Aditama

Sihotang, A. 2007. Manajemen Sumber Daya Manusia. Jakarta: PT. Pradnya Paramita.

Somantri, M. 2014. Perencanaan Pendidikan. Bogor: IPB Press.

Sugiyono. 2011. Metode Penelitian Kombinasi (Mixed Methods). Bandung: CV. Alfabeta.

Sunaryo, 2012. Manajemen Pendidikan Inklusif (Konsep, Kebijakan, Dan Implementasinya Dalam Perspektif Pendidikan Luar Biasa). Jakarta: UPI.

Susanto, H. 2012. Faktor-Faktor Yang Mempengaruhi Kinerja Guru Sekolah Menengah Kejuruan. Jurnal Pendidikan Vokasi. Vol. 2. No.2.

Tardi, R. 2011. Asesmen Hambatan Pendidikan Inklusif bagi Anak Penyandang Disabilitas di 3 Kabupaten di Nusa Tenggara Barat - Indonesia. Riset Dibiayai Uni Eropa.

Tarmansyah. 2009. Pelaksanaan Pendidikan Inklusifdi Sd Negeri 03 Alai Padang Utara Kota Padang (Studi Pelaksanaan Pendidikan Di Sekolah Ujicoba Sistem Pendidikan Inklusif ). Jurnal Pedagogi. Vol. IX No. 1.

Usman, H. 2013. Manajemen; Teori, Praktik, dan Riset Pendidikan. Jakarta: Bumi Aksara.

Usman, U. 2002. Menjadi Guru Profesional. Bandung: PT. Remaja Rosdakarya. 